Meta

Journal des traducteurs

Translators' Journal

\title{
French to English: Some Stylistic Considerations
}

\section{Gilbert Barth}

Volume 16, numéro 1-2, mars 1971

Actes du colloque international de linguistique et de traduction.

Montréal, 30 septembre - 3 octobre 1970

URI : https://id.erudit.org/iderudit/001980ar

DOI : https://doi.org/10.7202/001980ar

Aller au sommaire du numéro

Éditeur(s)

Les Presses de l'Université de Montréal

ISSN

0026-0452 (imprimé)

1492-1421 (numérique)

Découvrir la revue

Citer cet article

Barth, G. (1971). French to English: Some Stylistic Considerations. Meta, 16(1-2),

33-44. https://doi.org/10.7202/001980ar d'utilisation que vous pouvez consulter en ligne.

https://apropos.erudit.org/fr/usagers/politique-dutilisation/ 


\section{French to English: some stylistic considerations}

This Seminar has been discussing, and will continue to discuss the multiple aspects of translation and the closely allied, inseparable field of comparative linguistics. Everyone here readily subscribes to the proposition that translation is both an art and a science. It has been said that an art, as such, cannot really be analyzed, explained or imparted to anyone, one either possesses or lacks artistic, intuitive and creative talents. A science, on the other hand, can be analyzed, explained and transmitted. It is the scientific aspect of translation that is presently the center of our attention.

This report will concentrate on two techniques which all translators use, either consciously or unconsciously, namely, transposition and modulation. These techniques have been rather thoroughly described, analyzed and categorized by Jean-Paul Vinay and Jean Darbelnet in their work, Stylistique comparée du français et de l'anglais. It is a work with which, I am sure, you are all familiar, and to which I am deeply indebted. My contribution to the subject will be mainly of a statistical nature. On the basis of statistics, I hope to corroborate many of the intuitive observations already expressed by Vinay and Darbelnet, and to add a few conclusions and opinions of my own.

The statistics presented concerning transpositions are extracted from a much larger body of statistics contained in my work : Recherches sur la fréquence et la valeur des parties du discours en français, en anglais et en espagnol. Data and discussion shall be limited to the French and English languages, and to translation into English rather than into French. In the work just mentioned, the statistics were based on an analysis of 15000 words of original English texts (Graham Greene, Aldous Huxley and Virginia Woolf) and their translation into French : likewise 15000 words of French texts (Marcel Proust, Georges Bernanos and Antoine de Saint-Exupéry) and their translation into English. Illustrative examples, however, will be taken from other translations I have studied subsequently.

The statistics on modulation were gathered from a much smaller corpus : 7000 words of French and English texts and their translations. These include such authors as Samuel Beckett, George Blake, Evelyn Waugh, Wm. Faulkner, Julien Green, Ernest Hemmingway and Émile Zola.

Not included in any statistical count, but used as illustrative examples, 
shall be excerpts from four different translations of Flaubert's Madame Bovary, and the recent translation of Jean-Jacques Servan-Schreiber's le Défi américain.

The major part of the report shall concern transposition. Shorter space will be given to the length of translation, to modulation and to concluding remarks.

\section{TRANSPOSITIONS}

1.1. Definition and significance of transposition

The process of «transposition», as the term will be used in this paper, is the transference of the major semantic content or force of a certain part of speech in the original text to a different part of speech in the translation. At times this involves the disappearance, in the translation, of the original part of speech. For example :

Il n'est pas maître de sa mémoire. (Julien Green)

He could not control his memory.

Other times the original part of speech remains in the translated text but so much of its semantic content has been transferred that it is very much weakened or emptied of meaning or force :

The boy's body quivered... (Huxley)

Le corps $d u$ gamin eut $u n$ tressaillement...

In either case there is a grammatical shift of a semantic content, and this is one of the ingredients of style - though certainly not the only one. Admittedly each individual writer has his own style, his own idiolect, his own conscious or unconscious preference for one part of speech or another. Furthermore, if authors have an individual style, so does each translator. If, however, a sufficient number and variety of original texts in language « $A$ » are constrasted with their translations into language $《 B »-$ translations produced by a variety of translators - and if certain preferences or shifts consistently appear regarding the use of the various parts of speech, then, I believe, we can legitimately speak of these preferences as part of the stylistics of the language (la langue) as opposed to merely a part of the style of the writer or translator (la parole).

\subsection{General tendencies of French and English}

The following statistics are based on works mentioned in the introduction.

Direction of the transpositions in the French translations :

$\begin{array}{lrll}\text { toward the noun } & 1554 & \text { from the noun } & 308 \\ \text { toward the verb } & 936 & \text { from the verb } & 630 \\ \text { toward the adjective } & 361 & \text { from the adjective } & 815 \\ \text { toward the adverb } & 102 & \text { from the adverb } & 921 \\ \text { toward the particle } & 6 & \text { from the particle } & 285\end{array}$

(preposition and conjunctions)

Direction of the transposition in the English translations :

$\begin{array}{lllr}\text { toward the noun } & 596 & \text { from the noun } & 855 \\ \text { toward the verb } & 308 & \text { from the verb } & 961 \\ \text { toward the adjective } & 736 & \text { from the adjective } & 252 \\ \text { toward the adverb } & 570 & \text { from the adverb } & 130 \\ \text { toward the particle } & 48 & \text { from the particle } & 57\end{array}$


Aside from the last-mentioned statistic concerning the particle - which we will comment on later - the movement is exactly reversed in the two sets of translations.

I believe the above count is a sufficient basis for drawing the general conclusion that, in expressing equivalent semantic content, the French language favors more than English the use of nouns and verbs; and the English language is stylistically more oriented than is French toward the use of adjectives, adverbs and particles. The preference of these two languages for certain parts of speech is part of the stylistics of the languages and, as such, it should be significant to both French and English translators. Perhaps equally significant and practical will be some of the conclusions, or at least observations, I would like to propose, based on a closer look at some breakdowns of the above statistics. Let us now consider some specific categories.

\subsection{Certain categories of transpositions}

Although, in the case of just about every part of speech, the general direction of transpositions was reversed in the French and English translations, the number of transpositions was not always proportional; and in some instances this disproportion leads me to conclude that the English translators should have made greater use of certain categories of transpositions, the overall result of which would have been a closer conformity to the general stylistics of English. I shall limit myself here to presenting a few of the more significant disproportions.

\subsection{1.}

The noun. - The relative predominance or importance of the noun in French was an established datum, as far as French stylists were concerned, even before the exposé of Vinay and Darbelnet; so it should cause no surprise that French translators transposed toward the noun five times as often as they transposed from it $(1554-308)$. What is a surprise is the fact that English transposed from the noun only 855 times as compared to 596 transpositions toward the noun. One particular category that seems to be deficient in the number of transpositions is that of noun-verb. French translators transposed from verb to noun $\mathbf{5 2 5}$ times, almost twice as often as English translators transposed from noun to verb : 225 times. While it is very often possible to translate noun for noun and still produce an accurate and natural-sounding English sentence, translators, by failing to transpose, seem to miss many opportunities to make the sentence even more "English-sounding». Here is an extreme example taken from Ronald Steel's excellent translation of Servan-Schreiber's le Défi américain :

L'accélération récente des mouvements de concentration et de fusion en Europe a pour cause essentielle la nécessité de faire face aux géants américains comme IBM et General Motors.

Recent efforts by European firms to centralize and merge are inspired by the need to compete with the American giants like International Business Machine (IBM) and General Motors.

\subsection{2.}

The verb. - English stylists have always boasted about the expressiveness of the English verb. There seems to be little doubt that English possesses a 
greater variety of verbs, and the figures below concerning abstract-concrete modulations support the view that English verbs are more concrete and more specific than their French counterparts. This can be explained, at least in part, by the relative ease of derivation in English whereby almost any other part of speech can be used as a verb with little if any change in the form of the word. It might come as a surprise, therefore, that the count of transpositions shows that French translators transpose toward the verb more often than away from it (936 - 630); while the tendency of English translators is just the opposite (308 - 961). This indicates that, relative to French, English stylistics favors expressing important semantic content by other parts of speech, especially the adjective and adverb, leaving the verb rather weakened. This tendency is rather well established by the transposition count.

One type of transposition that English translators seemingly fail to take sufficient advantage of is «verb to adjective ». French translators transposed from the adjective to the verb 675 times; English translators went from the verb to the adjective only 192 times. Compare, for example, four of the many translations that have been made of Flaubert's Madame Bovary. I shall simply number them I, II, III, IV. The translator of II stated that his was merely a revised translation of I, so that in this and other examples given, I and II are exactly the same :

Elle était neuve; la visière brillait.

I, II The cap was new; its peak shone.

III It was a new cap, with a shiny peak.

IV The cap was new, its peak was shiny.

Only two of the four translators transposed to an adjective, but, I believe, with better results.

\subsection{3.}

The adjective. - As was shown above, the English translators consistently show their preference for the adjective, and the transposition shifts are rather proportional : French translators : 815 from the adjective, 361 toward it ; English translators : 252 from the adjective, 736 toward it.

\subsubsection{1.}

One category, noun-adjective, shows some disproportion, however. French transposition from the adjective to the noun number 674 ; English transposition from noun to adjective number only 480 . Simple opportunities like the following are often passed by : «son état-major pour l'Europe» - «its European headquarters $\gg$. And in a more literary vein :

Pour que la religion donne ses fruits elle a besoin de la charité. (Flaubert) In order to be fruitful, religion needs charity.

1.3.3.2.

A common construction in English is a noun used as an adjective to qualify another noun : «a brick house ». A transposition of this structure is almost always obligatory for a French translator; while the reverse is not true for English translators, since the structure « a house of brick» also exists. Although the former 
structure is perhaps more common than the latter in English, statistics show that translators often overlook this occasion to transpose :

... le curé de son village... (Flaubert)

I ... the cure of his village...

II ... the curé of his village...

III ... the priest of his village...

IV ... his village priest...

... les experts du Marché commun... (Servan-Schreiber)

... Common Market experts...

\subsubsection{3.}

Another frequent English structure that is conspicuous by its absence in English translations is the compound modifier. In the Madame Bovary translation, for example, only one of the four translators used it :

Ses jambes, en bas bleu, sortaient d'un pantalon jaunatre très tiré par les bretelles.

I His legs, in blue stockings, looked out from beneath yellow trousers, drawn tight by braces.

II His legs, in blue stockings, looked out from beneath yellow trousers, drawn tight by suspenders.

III His breeches were fawned-colored and braced up tight, his legs were clad in blue stockings.

IV His yellow breeches were hiked up by his suspenders, and from them emerged a pair of blue-stockinged legs.

... des gravures dans des cadres dorés... (Julien Green)

... gilt-framed engravings...

1.3.4.

The adverb. - Our statistics show an undeniable preference of English for the adverb : French transpositions toward the adverb : 102, and from the adverb : 921 ; English transpositions from the adverb : 130, and toward the adverb : 570 . Yet these figures are not exactly proportional, and indicate many missed opportunities to transpose. Steel takes advantage of an opportunity in the following example :

... plus du tiers de l'ensemble des investissements américains dans le monde. (Servan-Schreiber)

... more than a third of their total investment abroad.

A most common morphological structure in English is the adverb ending in «-1y». This occurs, however, much more rarely in English translations than it does in original English texts. Translators commonly transpose such phrases as avec ironie to « ironically», but many such occasions are missed :

Madame, par pudeur, restait tournée vers la ruelle et montra le dos. (Flaubert)

I, II Madame, in modesty, had turned to the wall and showed only her back.

III Madame remained modestly facing the wall, her back turned toward them.

IV Madame had modestly turned her back and lay facing the wall.

Steel makes use of the $"-1 y »$ adverb to substitute for a whole clause :

On s'aperçoit ainsi que le tissu de l'industrie européenne...

Obviously the fabric of European industry... 
1.3.5.

The particles. - The only trend in transposition that is not reversed in my statistics is that relating to the particles, that is, the prepositions and conjunctions. Both the English and French translations show a movement away from the particle to other parts of speech, or a strengthening of the particle by the addition of another part of speech or even a whole phrase or clause : an étoffement, to use the term of Vinay and Darbelnet. I could be justly accused of arbitrariness when I refuse to accept the statistics as indicating the relatively equal semantic content of French and English particles, were it not for several factors. First of all, there is practically universal agreement among comparative stylisticians that the English particle, especially the preposition, is semantically stronger than its French counterpart, so that it often needs the addition of other parts of speech to butress it when translated. Secondly, although the figures for both languages do register a greater number of cases of étoffement than for the reverse procedure, the proportion is in no way equivalent : French : 285 transpositions from the particle, as against 6 toward it ; English : 57 transpositions from the particle, as against 48 toward it. Lastly, I believe there is a natural reluctance on the part of translators to employ the reverse procedure, dépouillement, that is, the elimination of words, or their concentration into a simple preposition or conjunction. Perhaps this reluctance is due to a concern for complete accuracy, a hesitation to omit in their translation words that are specifically contained in the original. The translator of Virginia Woolf, for example, employs étoffement in the following clause :

... it was not to see anything that...

... ce n'était pas dans le but de voir quoi que ce fût que...

But if the translation had been the original text, how many English translators would have resisted employing «with the intention of $»$ and would have reduced the phrase to a simple preposition «to »? Compare two translations of a sentence of Flaubert :

La bonne ouvrit la lucarne du grenier et parlementa quelque temps avec un homme resté en bas dans la rue.

II The maid opened the attic window and parleyed for some time with a man who stood in the street below.

III The maid opened the attic window and parleyed for a while with a man in the street below.

Steel makes frequent use of dépouillement in his translation of le Défi américain :

Le centre de décision utilise les services du milieu financier constitué par ses principaux actionnaires...

The board of directors of a corporation uses the financial resources of its shareholders...

I might be accused of nit-picking here, and it may be argued that the use of dépouillement by English translators is not that important. But I believe continued failure to concentrate several words into prepositions and conjunctions that are capable of containing their semantic content will, in the long run, result in a noticeably wordy translation that will appear somewhat foreign to the principles of English stylistics. 
1.3.6.

Chassé-croisé. - One final type of transposition to be considered here is the chassé-croisé. This, of course, is an operation in which a double transposition is involved. It occurs commonly when translating from English into French. Since the stylistics of the French language is not so accustomed to express the manner of action by the verb, followed by the motion or direction of the action expressed by a preposition or adverb. Example :

She jerked her head back... (Faulkner)

Elle retira vivement la tête...

Unfortunately, in my study of transpositions, I did not keep a statistical record of the number of chassé-croisé occurrences. But on the basis of a much smaller corpus used to analyze modulations, the frequency of use by French translators was much higher than that of English translators : 10 as against 2 occurrences. Since the structure, verb of manner plus a preposition or adverb of motion or direction, is such a conspicuous element of English stylistics, its absence in the English translations points to the fact that many opportunities to effect a chassé-croisé are overlooked. Only one of the four translators of Madame Bovary made use of it in these sentences:

... le maître d'études fut obligé de l'avertir, pour qu'il se mît avec nous dans les rangs.

IV ... the teacher had to tell him to line up with the rest of us.

Le nouveau articula, d'une voix bredouillante, un nom inintelligible.

IV The boy stammered out some unintelligible noise.

\subsection{General observations on transpositions}

While the statistical study on transposition clearly indicates, in most cases, the relative preferences of French and English for certain parts of speech and certain structures, it also brings to light the failure of translators into English to take sufficient advantage of this translating technique. One counter-argument that can be given to the latter conclusion is the fact, or at least accepted hypothesis, that English structure is more flexible, more adaptable than French structure, hence there is not so great a need to transpose when translating into English. The overall number of transpositions recorded seems to confirm the greater flexibility of English : French translators transposed 2959 times (or one word in 15), while English translators transposed only 2255 times (or one word in 20 ). Yet I believe that «what is good for the goose is good for the gander », and that too close an adherence to the structure of the French original will result, in most cases, in a translation that may be acceptable in terms of understanding, but nevertheless somewhat deficient in terms of conformity to the principles of English stylistics; and in the long run a certain awkwardness or foreignness will be detectable.

It is true that the transposition of parts of speech is only one of the techniques of translation, and that translating techniques in general are only one aspect of the overall operation of translating, for translating is as much an art as a science. But I also believe that neglect of a single technique can have results that will mar the final product. 


\section{THE LENGTH OF THE TRANSLATIONS}

A side effect of my study on transpositions was a calculation of the number of words contained in the original texts and their translations. In each case the translation was longer than the original :

$\begin{array}{llll}\text { English texts } & 15249 & \text { French translations } & 17384 \\ \text { French texts } & 15139 & \text { English translations } & 15936\end{array}$

This might not be too surprising, considering that translations are commonly expected to be longer than original texts : there are undeniably vocabulary items, structures and ideas that simply require explanitory phrases or circumlocutions; and translators are more prone to add for clarity and precision than to omit for simplicity.

It is significant, however that French translators increased the number of words by $13 \%$, whereas the English translators increased the number by only $5 \%$. This can be another argument in favor of the relative flexibility of the English language. To carry this point to its logical conclusion, however, one should expect that the English translations should have contained $13 \%$ less words than the original French texts - or at least have been shorter. Whether this expectation is legitimate or not I have no way of proving; but I have come across a few English translations that were shorter than the original, and in each case I judged them to be good, and even excellent translations. Consider the reductions in the following excerpts from le Défi américain :

«Technological gap », «managerial gap», ces expressions qu'on est lassé d'entendre, sont usées avant même que leur signification ait pénétré dans les esprits. ( 24 words)

Terms like « technological gap» and «managerial gap» have become tired clichés even before we understand what they mean. (18 words)

... un effort de rationalisation et de progrès qu'ils n'auraient pas consenti s'il n'avait pas été placé sous la pression de cette concurrence. (26 words) ... a rationalization and modernization they would never have accepted without such competition. (12 words)

Only one of four translators shortened this clause of Flaubert :

... son habit-veste de drap vert à boutons noirs devait le gêner aux entournures. (14 words)

I, II ... his short school jacket of green cloth with black buttons must have been tight about the armholes. (17 words)

III He had on a short green jacket with black buttons, which must have pinched him under the arms... (18 words)

IV ... his green jacket with black buttons seemed tight under the arms. (11 words)

In striving for concision there is always the danger that an important nuance will be lost. On the other hand, overconcern about including even the most insignificant detail will certainly bog down the translation. If the English language is more flexible and more concise than French — and I believe it is - English translations should logically be shorter, in most cases, than the original French text. The text and its translation are supposed to convey the same message, are supposed to express the same semantic content; if the translation is excessively longer, its general effect will be wordiness, and this runs counter to the stylistics of English as compared to French. 


\section{MODULATIONS}

Another technique in translation which has been singled out by Vinay and Darbelnet is what they term modulation, and which they define as a change in the point of view. This is a very general definition and can include such categories of change as : abstract-concrete, cause-effect, means-result, part-whole, one part for another part, duration-date, distance-destination, form-usage, positive-negative, active-passive, space-time, and a few others.

It was my intention to conduct a statistical study on modulations, similar to the one completed on transpositions, and to include the results in this paper. Time worked against me. I soon discovered that identifying modulations was a much more subtle, arduous and time-consuming task than identifying transpositions. Modulations can occur not only on the word level, but on the phrase, clause and sentence level. They are sometimes simultaneous with transpositions, and sometimes not. At times they are very obvious and clearly defined, at times they are hidden and mere matters of judgement or opinion. Even with a small corpus of 7000 words of French and English texts I no doubt failed to recognize many of the modulations that took place in the translations. Some categories mentioned by Vinay and Darbelnet $I$ did not encounter at all; instances of other types equalized themselves in number so that no specific trend or preference was discernible. My remarks here, therefore, shall be limited to two types of modulations which were the most numerous, or at least the most obvious : abstract-concrete, and positive-negative.

\subsection{Abstract - Concrete}

It is often difficult to draw a line of demarcation between what is abstract and what is concrete - after all, every word is an abstraction. The distinction between abstract and concrete is polar, and every word occurs at some point between these poles. It can be said that a word is concrete or abstract only in relation to another word.

I found the terms «general » and «specific » more helpful in my judgement. If the idea expressed by word «a» was contained or encompassed by the more general word $\langle b »$, I considered $\ll a »$ to be more concrete. The only instances of the modulation, abstract-concrete, that were tallied were those I considered obvious and undebatable.

As can be expected, French translations went from the concrete, specific expression to the abstract or general word 55 times, while going in the opposite direction only 17 times. Examples :

He hesitated a moment then he wrote : ... (Graham Greene)

Il hésita un moment et ajouta : ...

Women made such swell friends... (Hemmingway)

Une amitié avec une femme, c'est tellement chic...

English translators went toward the concrete 37 times and toward the abstract only 6 times. Examples :

D'autres sont faits pour la lutte. (Julien Green)

Others are cut out for wrestling with life. 
Il faudra vous décider à en acheter un autre... (Zola)

You're going to have to break down and buy another one...

The reverse tendencies of the two languages are definite and proportionate. As the figures indicate, however, English translators make this modulation less often. As an example, two translators of Flaubert gave a more concrete verb for jeter and two did not :

Nous avons l'habitude, en entrant en classe, de jeter nos casquettes par terre...

I, II When we came back to work, we were in the habit of throwing our caps on the ground.

III It was our habit, on returning to class, to fling our caps under the bench.

IV We always flung our caps on the floor when entering a classroom.

(Note also in the last translation : a transposition of the abstract habitude to the adverb «always»; «classroom» can be considered more concrete than «class »; there are less words than in the original.)

\subsection{Positive - Negative}

The French translators went toward the negative 14 times and toward the positive 10 times. These figures in themselves are not impressive enough to prove a definite trend. On some occasions a negative particle is used, other times it is not :

She backed away on hands and knees, watching it. (Faulkner)

Elle recula à quatre pattes, ne le quittant pas des yeux.

... a dull, middle-aged police officer who failed for promotion. (Graham Greene)

... un officier de police entre deux âges, sans attraits, et qui n'a pas même eu sa promotion.

English translators, on the other hand, shifted toward the positive twice as often (20 times) as they did toward the negative (10 times). The following examples from Samuel Beckett, who was his own translator, show that the negative particle can be lost from the sentence $(a)$ and $(b)$; a negative word can be changed to a positive one $(c)$; or a whole idea can be expressed in a positive manner $(d)$ :

Ça ne va pas vite.

(a) This is slow work.

Ce n'est pas vrai!

(b) It's a lie !

La fin est inouïe.

(c) The end is terrific.

Vous m'empêcher de dormir.

(d) You're keeping me awake.

\section{CONCLUSION}

As for my remarks on modulations, I regret that my statistical research was not extensive enough to determine any trends in the many other categories, or even to draw definitive conclusions on the two categories treated. Perhaps some who hear or read this paper will become stimulated to continue research in this area. In my opinion, statistical data to show the point of view different languages 
prefer in expressing the same message would be of great interest and help to both linguists and translators.

In the age of the computer, it should be no great problem to expand our knowledge of comparative stylistics by using a large body of good translations as a basis for gathering statistical data on the frequency and relative use of various grammatical structures, and their position in the sentence - not to mention the broader realm of discourse analysis. Furthermore, since various English styles have already been contrasted on the basis of generative grammar, there seems to be no reason why translations could not be contrasted with original texts on the same basis.

As for the statistics and remarks concerning transpositions, my only hope is that they will prove useful, or at least thought-provoking, to those in the field of comparative stylistics and translation.

Gilbert Barth

\section{BIBLIOGRAPHY}

\subsection{Statistical data on transpositions}

BARTH, Gilbert, Recherches sur la fréquence et la valeur des parties du discours en français, en anglais et en espagnol, Paris, Didier, 1961.

\subsection{Texts and translations for statistics on transpositions}

Bernanos, Georges, Sous le soleil de Satan, Paris, Plon, 1952. Under the Sun of Satan, translated by Harry L. Binsse, New York, Pantheon, 1949.

GrEeNE, Graham, The Power and the Glory, London, Vanguard, 1952. La Puissance et la gloire, translated by Marcelle Sibon, Paris, Robert Laffont, 1948.

HuXleY, Aldous, Brave New World, Garden City, Doubleday, 1932. Le Meilleur des mondes, translated by Jules Castier, Paris, Plon.

Proust, Marcel, A la recherche du temps perdu, tome II : le Côté de Guermantes, Paris, N.R.F., 1919.

The Guermantes Way, translated by C.K. Scott Moncrieff, New York, Random House, 1952.

SAINT-Exupéry, Antoine de, Vol de nuit, Paris, Gallimard, 1931. Night Flight, in Airman's Odyssey, translated by Stuart Gilbert, New York, Reynal and Hitchock, 1942.

Woolf, Virginia, To the Lighthouse, London, Hagarth Press, 1927. La Promenade au phare, translated by M. Lanoire, Paris, Stock, 1957.

\subsection{Texts and translations for statistics on modulations}

BecKetт, Samuel, Fin de partie, Paris, Editions de Minuit, 1957. Endgame, translated by the author, London, Faber \& Faber, 1958.

BonNerot, L. et al., Chemins de la traduction - domaine anglais, Paris, Didier, 1963 (texts and translations of G. Blake, V. Woolf, E. Waugh).

FAulkner, Wm., Sanctuary, Penguin Books, 1955.

Sanctuaire, translated by R. N. Raimbault and Henri Delgove, Paris, Gallimard, 1949.

Goodall, G.T. and A. Joly, Thèmes anglais, Paris, Didier, 1965 (texts and translations from G. Flaubert, A. France, O. Mirbeau and J. Renard).

Green, Julien, Chaque homme dans sa nuit, Paris, Plon, 1960. Each in His Darkness, translated by Anne Green, New York, Pantheon, 1960.

GreENe, Graham, Heart of the Matter, New York, Viking, 1948. $\mathrm{Le}$ Fond du problème, translated by Marcelle Sibon, Paris, Laffont, 1949.

HeMmingway, Ernest, The Sun also Rises, New York, Scribner's, 1927. Le Soleil se lève aussi, translated by M. E. Coindreau, Paris, Gallimard, 1949.

ZorA, Emile, la Faute de l'abbé Mouret, Paris, Gallimard, "Bibliothèque de la Pléiade ". 1960.

The Sin of Father Mouret, translated by Sandy Petry, N. J., Prentice-Hall, 1969. 
5.4. Texts and translations for supplementary illustrations

Flaubert, Gustave, Madame Bovary, Paris, Garnier, 1961.

(I) Madame Bovary, translated by Eleanor Marx Aveling, Book League of America, n.d.

(II) Madame Bovary, translated by Paul De Man (based on the Aveling translation), W. W. Norton, 1965.

(III) Madame Bovary, translated by Alan Russell, New York, Penguin Books, 1950.

(IV) Madame Bovary, translated by Francis Steigmuller, New York, Random House, 1957.

Servan-Schreiber, Jean-Jacques, le Défi américain, Paris, Denoël, 1967.

The American Challenge, translated by Ronald Steel, New York, Atheneum, 1968.

\subsection{Relevant books and articles}

Antosch, Freiderike, "The Diagnosis of Literary Style with the Verb-Adjective Ratio", in Statistics and Style, ed. by Luboner Dolzel and Richard Bailey, New York, American Elsevier Publishing Co., 1969.

BODNer, David, "The Adjective-Verb Quotient», Psychological Record, vol. III (1940), p. 309-343.

Charleston, Britta, Studies on the Emotional and Affective Means of Expression in Modern English, Bern, Franke, 1960.

HaYes, Curtis W., "A Study in Prose Styles », in Statistics and Style, ed. by Luboner Dolzel and Richard Bailey, New York, American Elsevier Publishing Co., 1969.

MrLes, Josephine, Style and Proportion : The Language of Prose and Poetry, Boston, Little and Brown, 1967.

Nma, Eugene, Toward a Science of Translating, Leiden, E. J. Brill, 1964.

OHMANN, Richard, "Generative Grammar and the Concept of Literary Style », Word, 20 (1964), p. 423-439.

VinaY, Jean-Paul and Jean Darbelnet, Stylistique comparée du français et de l'anglais, Paris, Didier, 1958. 